\title{
Uncertainty, Impermanence Syndrome, and Public Land Ranching
}

\author{
By Samuel F. Parry and Rhonda Skaggs
}

\section{On the Ground}

- Impermanence syndrome involves farmer apprehension or uncertainty about the future and leads to disinvestment in an agricultural operation as well as erosion of producer confidence.

- We explored impermanence syndrome among New Mexico public rangeland cattle producers in order to assess perceptions of impermanence syndrome impact factors in the region.

- Urban fringe effects, proximity to the US-Mexico border, multiple-use of public rangelands, public perception of public land ranching, as well as economic and government agency issues were identified as causes of ranching impermanence syndrome.

- Mitigation of uncertainty and perceived impermanence threats to ranching would promote management and investments that promote longhaul planning for and enhancement of rangeland health.

Keywords: impermanence syndrome, ranching, public lands, southwestern United States, disinvestment, US-Mexico border, land use, cattle industry.

\section{Rangelands 36(2):20-24}

doi: 10.2111/RANGELANDS-D-13-00034.1

(C) 2014 The Society for Range Management

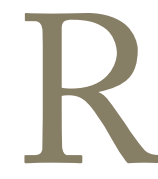

anch and rangeland sustainability are contingent upon numerous actors, actions, and forces, including uncertainty about the future. Uncertainty affecting agricultural operations' planning and investment decisions can lead to impermanence syndrome, which is the perception that long-term prospects for continued agricultural production and land use are uncertain. ${ }^{1-3}$ The response is economically rational disinvestment of capital resources, declining infrastructure maintenance, loss of efficiency, and loss of income to the operation..$^{4-6}$ Imperma- nence syndrome undermines producer confidence, hampers long-term planning, and encourages speculation. In some settings, impermanence responses may be premature and unmerited. ${ }^{5,7,8}$ However, ineffective responses to either real or perceived impermanence threats can undercut farm-level profitability and viability. ${ }^{6}$

Urbanization is often the primary impermanence-syndrome factor affecting agricultural producers (e.g., crop and dairy farms located on the urban fringe). However, urbanization as a source of uncertainty is not typical of livestock ranching conditions throughout much of the western United States, particularly in remote areas with extensive public land grazing. In land-extensive western ranching conditions, an individual ranch operator's decisions and reactions to various pressures can influence conditions on thousands of acres, ${ }^{9}$ many of which may be in the public domain and ecologically fragile. Thus, better understanding of the degree to which a wide variety of impermanence factors are perceived to impact public land ranching is critical to improved land management and policy formulation.

\section{Impermanence Issues Affecting Southwestern New Mexico Ranches}

We surveyed public land ranchers in southwestern New Mexico (via mail, telephone, and in-person interviews) in 2011 in order to assess their perceptions of possible ranching impermanence factors. One hundred and forty-one ranchers representing 191 grazing allotments across eight counties within the federal Department of Interior Bureau of Land Management's (BLM) Las Cruces District completed a questionnaire. These responses accounted for $35 \%$ of public land ranches and $47 \%$ of the BLM grazing allotments in the study area.

The survey instrument included questions that covered specific issues related to ranch proximity to the US-Mexico border, multiple-use of public lands, public perceptions, urbanization, economic issues, government agency, and environmental issues. The questions were designed to identify ranchers' perceptions of ranch management impact factors (e.g., potential sources of impermanence syndrome). 
We used a five-point Likert Scale ${ }^{10}$ to measure whether a specific factor was perceived to impact a respondent's ranch positively or negatively. Anecdotal feedback prior to the study indicated that some impact factors were viewed positively by some ranchers in the region and negatively by other ranchers (e.g., hunting, presence of big game, etc.); therefore, the scale was designed to avoid biasing responses to the impermanence impact factor questions. The five point scale ranged from -2 to +2 allowing respondents to choose whether the impact of a particular factor was very negative (-2), somewhat negative (-1), no impact (0), somewhat positive $(+1)$, or very positive $(+2)$. For each question respondents were also asked to indicate the level of impact on their ranches they expected the impact factor to have in the next five years using the same scale. Multiple questions were included in the survey for each category of potential impermanence factors. Ranchers' responses to the different categories of potential impermanence-syndrome factors are discussed below.

Ranchers' Perception of US-Mexico Border Issues Ranchers reported that US-Mexico border issues negatively impact their ranches. Survey respondents indicated negative effects of US Border Patrol (USBP) enforcement activities as well as human and drug trafficking, and viewed the ranching impacts of human and drug trafficking in the region much more negatively than USBP enforcement activities. Ranchers reported that they did not expect USBP activities in the region to change in the next five years and that they expected human and drug trafficking activities will get worse.

\section{Ranchers' Perception of Multiple-Use Issues}

Multiple-use public rangeland impermanence issues included in the survey covered off-road vehicle recreation, camping, hunting, rock hounding, sand and gravel extraction, oil and gas exploration and extraction, and the presence of historical or archeological sites on the ranch. Without exception, ranchers perceived each of the multiple-use factors as negatively impacting their ranching operations, but they also expected impacts from off-road vehicle recreation, camping, rock hounding, and historical or archeological sites either to decrease or remain constant over the next five years. Ranchers' current and predicted assessments of both hunting and the sand, gravel, oil, and gas extraction or exploration factors did not change.

\section{Ranchers' Perception of Urbanization Issues}

Survey questions asked respondents whether any of the following urbanization-related factors impacted their ranches: public animal-welfare scrutiny; urban proximity; vandalism; proximity of transportation corridors including roads, interstate highways, and railroads; and the presence of public easements. Respondents reported negative ranch-level impacts for each of the urbanization-related questions, and with the exception of railroad corridors, indicated they believed each urbanization-related factor was expected to get worse in the next five years.

\section{Ranchers' Perception of Economic Issues}

Economic issues that ranchers responded to included labor availability, property taxes, and inheritance taxes. All issues were perceived by ranchers to negatively impact their ranches and were expected to get worse in the next five years.

\section{Ranchers' Perception of Environmental and Agency} Issues

Respondents perceived environmental organizations as a threat to their ranches. Survey questions covered the perceived impacts of the Endangered Species Act, wolf reintroduction, wilderness study areas, a proposed legislatively designated wilderness area in the region, and wildlife. Ranchers' greatest perceived threat appeared to be wolf reintroduction; they also believed that their ranches will be more negatively impacted by wolf reintroduction in the future. Ranchers' responses to all the survey questions assessing impermanence factors related to environmental and land management agency administrative issues indicated that these factors are believed to be negatively impacting ranching and will continue to do so for the next five years.

\section{Comparing Rancher Subgroups}

Overall, respondent ranchers viewed the potential impermanence impact factors explored in the survey as negative and generally have negative expectations about the five-year future for each impermanence impact factor. We further categorized respondents into subgroups based on their responses to various survey questions and a test of means was performed to determine if differences existed between subgroups. Our analysis revealed that ranch owner-operators perceived the impact of transportation corridors, labor availability, and property and inheritance taxes on ranching less negatively than did absentee ranch owners and ranch managers. Ranchers who rely on ranching as a primary source of income viewed animal-welfare scrutiny, labor availability, environmental issues, proposed wilderness areas, alternative energy development, and presence of game wildlife species as having less of a negative impact on their ranches than did respondents who said ranching was a secondary source or not a source of income (although both groups still perceived each of these factors negatively).

We observed some differences between ranchers who had exercised a temporary non-use option on their public land grazing allotments and those who had not. Ranchers who had taken advantage of non-use provisions (primarily due to drought) viewed multiple-use of public land as having less of a negative impact on their ranches than did other respondents. Ranchers who had taken non-use also viewed sand and gravel extraction, oil and gas exploration and extraction, and hunting activities less negatively than respondents who had not used non-use provisions. The same was true for imposi- 
tions from easements, the railroad corridor, vandalism and urban proximity - ranchers who had exercised non-use options saw these as less of a problem for their ranches. There was no difference in responses between those who planned an intergenerational family ranch transfer and those who did not with respect to any of the impermanence factors.

Analysis of spatial subgroups also revealed some differences in impermanence perceptions among survey respondents. As would be expected, ranchers closer to population centers report more negative opinions of the impacts of urban encroachment on their ranches than those located farther from population centers. Respondents from ranches located farther from towns report less of an impact from archeological and historic sites occurring on the allotments they use. Archeological and historic sites closer to urban areas likely receive more public visitation than sites located on allotments farther from a population center; however, these results may be confounded by the actual geographic distribution of significant archeological and historic sites.

Ranchers operating farther than 50 miles from the border report less negative ranching impacts from US-Mexico border-related factors. It is clear that perceived negative impacts stemming from border issues such as illegal trafficking and law enforcement are a function of ranch distance from the border and are spatially dependent. However, differences in ranchers' perceptions of the ranch-level impact of wolf reintroduction between respondents whose ranches are located within 40 miles of the designated reintroduction area and ranchers farther than 40 miles are not spatially dependent, with both subgroups reporting similarly negative perceptions of reintroduction. Because the subject of wolf reintroduction is such a controversial one, ranchers' responses to questions about the perceived impact of wolf reintroduction likely reflected their overall opinion of the wolf reintroduction issue and not necessarily the impact of wolves on their ranch.

Dividing respondents by ranch size (greater than 20,000 acres and less than 20,000) yielded some differences in perceptions of potential ranch-level impermanence impact factors. Larger ranches perceived multiple-use issues, including extractive activities, historic or archeological sites, and recreation more negatively than respondents with smaller ranches. Ranchers in the larger size group perceived urbanizationrelated threats more negatively and also indicated that labor availability was more of a negative issue for them.

Respondents who noted they were primarily profit-driven in their ranch management decisionmaking reported more negative impacts from public land multiple-use factors than other respondents. The same primarily profit-driven ranchers also indicated that their ranching operations were more negatively impacted by labor availability, environmental issues, proposed wilderness areas, and alternative energy proposals than other respondents.

Where differences did exist between subgroups of survey respondents, greater negative ranch-level impacts of the potential impermanence factors were perceived by ranchers who were not owner-operators and who did not derive their primary source of income from ranching but who did indicate that ranch profitability is important to them. Furthermore, operators of larger ranches that are closer to the source of impact and ranchers who had never taken advantage of temporary non-use of allotment grazing, all perceived many of the impermanence impact factors more negatively than their opposite counterparts.

\section{Implications for Ranching in the Desert Southwest}

According to one survey respondent, "Saving ranches and open spaces benefits ranchers as well as the environment. Urban development and subdivision of ranches endangers ranches as well as the species that live there. Private land (ranches) that join public land increase open spaces for wildlife." With this statement, this anonymous survey respondent confirmed the notion that ranchers play an important (or keystone) role ecologically. ${ }^{1-14} \mathrm{~A}$ different survey respondent commented, "I feel the ranchers and farmers are better at protecting the environment than the government because [ranchers and farmers] know the consequences if they do not."

Ranchers who are equipped with the resources and knowledge to manage for a sustainable ecosystem likely strive to do so; however, ranchers face many challenges that are unique to their location or use of state and federal grazing allotments and that may limit best practice management of the rangeland resources. How these challenges and impacts are perceived influences ranchers' day-to-day management decisions, as well as their long-term goal setting, planning, and investing. Ranchers with negative impermanence perceptions may allocate resources to mitigate the effects of or in response to external uncertainty-causing impact factors. These individuals are likely to be less enthusiastic about their role as long-haul environmental stewards.

It was not the intent of our research to reflect a pessimistic bias or unreasonable negativity among the rancher population surveyed; questions were designed to minimize biased responses. However, the summary of responses to the survey indicate that ranchers in southwestern New Mexico generally believe that their ranching operations are being negatively affected by border, multiple-use, urbanization, economic, environmental, and agency issues, and that these negative impacts will continue in the future.

Our study documented ranch-level sources of impermanence perceptions that can contribute to uncertainty and impermanence syndrome in the region's ranching community. It is unknown to what extent capital investment and infrastructure maintenance on ranches has been or is being curtailed as a result of impermanence syndrome and whether or not rangeland health has been impaired due to negative perceptions of impermanence issues. At this point, we can hypothesize as to how negative perceptions about the future of ranching in the region may alter behavior and constrain 
ranch and range management. Holding all else constant, the implications of impermanence syndrome among public land ranchers are varied but are expected to directly and indirectly affect ecosystem health for the worse. This hypothesis needs to be rigorously tested.

Our research assessed ranchers' perceptions of various sources of ranch management uncertainty that can result in impermanence syndrome. These perceptions may or may not be grounded in reality. However, perceived impermanence threats and an uncertain future can negatively influence ranch management and long-term planning even if the fears are unfounded. Impermanence and uncertainty were reflected in this comment from a rancher who said, "Ranch leases may not exist to transfer to [the] next generation..." and in the comments of another rancher who wrote, "I plan to turn the ranch over to my kids when I am too old to handle the work. I hope they will be able to continue?" The last statement ended with a question mark that indicates how many of the responding ranchers appear to view the future. Perhaps that is why one out of five ranchers in this study reported they didn't plan to transfer the ranch to another family member.

Understanding ranchers' perceptions of impermanence factors is an important first step in understanding how their management decisionmaking can potentially impact millions of acres of rangeland. The perceptions can be summed up by a surveyed rancher who stated "I'm not normally a pessimistic person, but I don't foresee a very promising future for ranching" and another rancher who said "[Ranchers] are fighting a long retreat." Because of ranchers' role in safeguarding rangeland health and productivity, the results of this research are somewhat alarming. Increases in ranching operation transience due to uncertainty and perceived impermanence threats could translate into increased environmental vulnerability. An anonymous rancher commented in the survey, "There's no incentive for investments or improvements." For this rancher and potentially many others, the cost, in terms of time and resource allocation for range improvement projects, including brush control and other efforts to mitigate desertification, are not offset by the benefits of the investment due to their impermanence perceptions.

Public land management agency personnel work with ranchers on a daily basis. How do agency staff perceive ranchers' perceptions of and responses to impermanence factors and how do they perceive impermanence factors themselves? How do policy makers in the state and the nation's capital view these impacts to ranch management and to the public domain rangelands? It is likely that public land management agency personnel would have some of the same impermanence perceptions as ranchers, but policy makers' perceptions might be extremely different. Ranchers have their perceptions of impermanence factors, agency personnel have their perceptions, and policy makers have theirs; which perception more accurately reflects reality and what are the appropriate policy responses?
At what point do impermanence issues become too difficult to handle on the ranch or by the public land management agency? For example, how risky does US-Mexico borderland ranching have to get, or how much vandalism can ranches absorb before the costs outweigh the benefits and ranchers say, as one rancher stated in an interview regarding this issue, "Oh, forget it!"? Public land management agencies in the region also have cost-benefit calculations that may eventually reach tipping points where certain public domain lands become too costly to manage for grazing or are simply unmanageable for any use. Tipping point incongruence between the public land grazing permittee and the land management agency would potentially be an additional source of public land policy and regulatory conflict.

Not surprisingly, the results of this research have raised additional and complicated questions about the future of public land ranching in the desert southwest. As with most complex problems, answers and solutions lie with a multifaceted approach including multiple stakeholders. People interested in mitigating the anthropogenic effects of rangeland degradation can support policies that strengthen ranch management decisionmaking to improve rangeland health, empower ranch sustainability, and alleviate impermanence perceptions and uncertainty among public land ranchers. Mitigation of uncertainty and perceived impermanence threats to ranching would promote management and investments that promote long-haul planning for and enhancement of rangeland health.

\section{References}

1. Berry, D. 1978. Effects of urbanization on agricultural activities. Growth and Change 9:2-8.

2. Berry, D., And T. Plaut. 1978. Retaining agricultural activities under urban pressures: A review of land use conflicts and policies. Policy Sciences 9:153-178.

3. Sharp, J. S., And M. B. Smith. 2003. Social capital and farming at the rural-urban interface: the importance of nonfarmer and farmer relations. Agricultural Systems 76:913-927.

4. Lisansky, J. 1986. Farming in an urbanizing environment: agricultural land use conflicts and right to farm. Human Organization 45:363-371.

5. Lopez, R. A., A. O. Adelaja, and M. S. Andrews. 1988. The effects of suburbanization on agriculture. American Journal of Agricultural Economics 70:346-358.

6. Nelson, A. C. 1992. Preserving prime farmland in the face of urbanization. Journal of the American Planning Association 58:467-488.

7. Lockeretz, W. 1986. Trends in farming near cities. Journal of Soil and Water Conservation 41:256-262.

8. Hirschl, T. A., ANd N. L. Bills. 1993. Urban influences on farmland use in New York State. Working Papers in Agricultural Economics-Cornell University 93.

9. Johnson, S. G. 1998. Oaks at the edge: land use change in the woodlands of the Central Sierra Nevada, California [disserta- 
tion]. Berkely, CA, USA: University of California, Berkeley. $267 \mathrm{p}$.

10. Dillman, D. A. 2000. Mail and internet surveys: the tailored design method. New York, NY, USA: John Wiley \& Sons. $464 \mathrm{p}$.

11. Knight, R. L., W. C. Gilgert, and E.Marston. 2002. Ranching west of the 100th meridian: culture, ecology, and economics. Washington, DC, USA: Island Press. 259 p.

12. Sayre, N. F. 2005. Interacting effects of landownership, land use, and endangered species on conservation of southwestern U.S. Rangelands. Conservation Biology 19:783-792.

13. Knight, R. L. 2007. Ranchers as a keystone species in a West that works. Rangelands 29:4-9.
14. Talbert, C. B., R. L. Knight, and J. E. Mitchell. 2007. Private ranchlands and public land grazing in the southern Rocky Mountains. Rangelands 29:5-8.

Authors are Former Graduate Research Assistant (Parry) and Professor, rskaggs@nmsu.edu (Skaggs), Agricultural Economics and Agricultural Business, New Mexico State University, Las Cruces, NM 88003, USA. This work was supported by the National Science Foundation, NSF Grant DEB-0618210, as a contribution to the Jornada Long-Term Ecological Research (LTER) program, by the New Mexico Agricultural Experiment Station, and by the United States Department of Agriculture-National Institute of Food and Agriculture (USDA-NIFA). 